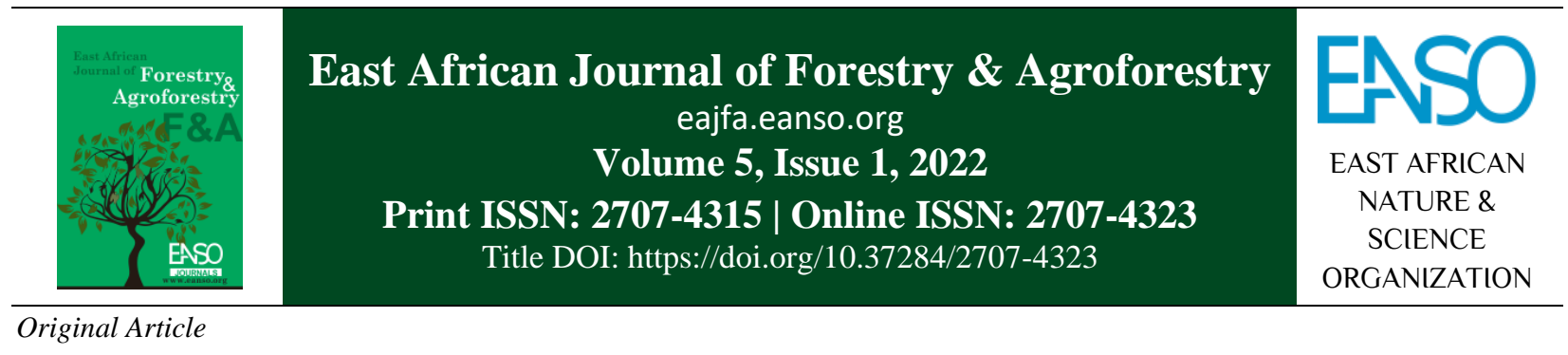

\title{
The Implication of Covid-19 on Forest in Malawi.
}

\author{
Chizoba Obianuju Oranu ${ }^{l^{*}}$, Linda Chinenyenwa Familusi ${ }^{2}, \&$ Kehinde Paul Adeosun ${ }^{l}$ \\ ${ }^{1}$ Department of Agricultural Economics, University of Nigeria, P. M. B. 410001, Nsukka, Enugu State, Nigeria. \\ ${ }^{2}$ Department of Agricultural Economics and Extension, University of Port Harcourt P. M. B 5323, Choba, Rivers State, Nigeria. \\ * ORCID: https://orcid.org/0000-0002-4293-3816; Author for Correspondence email: chizoba.oranu@unn.edu.ng.
}

Article DOI: https://doi.org/10.37284/eajfa.5.1.530

\section{Date Published: ABSTRACT}

17 January 2022 The rate of deforestation and degradation of forests in Malawi has been remarkably high as a result of high dependency on forests for cooking fuel,

Keywords: expansion of agriculture and population growth. Similarly, forests in Malawi are a source of livelihood, as well as safety nets for rural communities in

Forest, times of unanticipated scarcity of food or as gap fillers during regular COVID-19, seasonal shortfalls of food supply. The forest sector also supports agriculture Deforestation, which is the backbone of the economy in various ways such as in soil erosion Malawi. management, soil fertility improvement, and water flow regulation. These have made the forest sector key in economic growth and poverty alleviation in Malawi, which is among the world's poorest countries. Hence, the forest sector in Malawi is of great importance to sustainable livelihood and development. However, the high dependence on forests particularly among rural households is prone to exacerbate deforestation and degradation of forests in the COVID-19 pandemic era. This is so because Malawi, just like in other parts of the world has experienced a decline in household income and loss of jobs as a result of the pandemic, leading to increased pressure on forests, especially among forest-dependent households. This study looked at the implication of COVID-19 on the forest sector in three ways; the demand and supply of forest products as well as forest management, by reviewing relevant literature. The review showed that the COVID-19 precautionary measures such as restriction of movement and closure of border disrupted the supply chain of forest resources, which resulted in a demand shortage. Also, the "work from home" measure, which keeps forest guard away from forests increasing the exploitation of forest and forest conservation training programmes as well as impedes tourism to forest reserves. Therefore, the knowledge of the implication of COVID-19 on Malawi's forest is core in building a resilient and sustainable post-COVID-19 economy.

\footnotetext{
1 | This work is licensed under a Creative Commons Attribution 4.0 International License.
} 


\section{APA CITATION}

Oranu, C. O., Familusi, L. C., Adeosun, K. P. (2022). The Implication of Covid-19 on Forest in Malawi East African Journal of Forestry and Agroforestry, 5(1), 1-8. https://doi.org/10.37284/eajfa.5.1.530

\section{CHICAGO CITATION}

Oranu, Chizoba Obianuju., Linda Chinenyenwa Familusi, Kehinde Paul Adeosun. 2022. "The Implication of Covid-19 on Forest in Malawi”. East African Journal of Forestry and Agroforestry 5 (1), 1-8. https://doi.org/10.37284/eajfa.5.1.530.

\section{HARVARD CITATION}

Oranu, C. O., Familusi, L. C., Adeosun, K. P. (2022), “The Implication of Covid-19 on Forest in Malawi”, East African Journal of Forestry and Agroforestry, 5(1), pp. 1-8. doi: 10.37284/eajfa.5.1.530.

\section{IEEE CITATION}

C. O. Oranu, L. C. Familusi, K. P. Adeosun, “The Implication of Covid-19 on Forest in Malawi”, EAJFA, vol. 5, no. 1, pp. 1-8, Jan. 2022.

\section{MLA CITATION}

Oranu, Chizoba Obianuju., Linda Chinenyenwa Familusi, Kehinde Paul Adeosun. "The Implication of Covid-19 on Forest in Malawi”. East African Journal of Forestry and Agroforestry, Vol. 5, no. 1, Jan. 2022, pp. 1-8, doi:10.37284/eajfa.5.1.530.

\section{INTRODUCTION}

There is no doubt that the coronavirus (COVID-19) pandemic came unexpected and a lot of countries including Malawi were not prepared for the likely impact of the pandemic. Malawi reported its first COVID-19 cases on April 22020 and since then, cases have continued to rise. Though the impact of COVID-19 cannot yet be fully quantified following the uncertainty around the pandemic, there have been notable impacts in the world economies. Across the world, various sectors of the economies have been affected, resulting in a decline in economic growth and projection of a further decline in Gross Domestic Product (GDP) that might lead to global economic recession, loss of jobs, fall in demand and supply of goods and services, disruption of the education system and disrupted food supply chain (Ozili \& Arun, 2020; Haleem et al., 2020; Congressional Research Service (CRS, 2021); Maliszewska et al., 2020; Gondwe, 2020).

The GDP of Malawi is among the lowest in the world and agriculture is the major contributor to the country's GDP (World Bank, 2021). Agriculture accounts for approximately $30 \%$ of the country's GDP and $65 \%$ of employment as well as generates over $80 \%$ of national export earnings (Government of Malawi, 2020). With a growing population of approximately eighteen million and the rural population making up $84 \%$ of the total population, expansion of agriculture and settlements, as well as unsustainable fuelwood extraction are the key drivers of deforestation (Malawi Government,
2016). The rate of deforestation can further be exacerbated by increased poverty due to the pandemic. In most parts of the world, the pandemic has aggravated poverty, which is already at a high rate of 50.7\% in Malawi (United Nations, 2021, World Bank, 2021). According to Nerfa et al. (2020), there is an interrelation between poverty and dependence on forests in diverse ways. Hence an increase in poverty leads to pressure on forests, as poor households will depend on forests for household food supply and cooking fuel.

Notwithstanding that there is a high rate of poverty in Malawi, which is already putting pressure on the forest, the COVID-19 pandemic has led to increased pressure on forests. This is so because the COVID19 has led to significant loss of jobs, halting or delay of development projects and decline in household income, which has resulted in pressure on forests as a coping strategy, particularly among adjacent forest communities (International Labour Organization, 2020). In addition, some of the COVID-19 precautionary measures such as the closure of borders, restriction on movement and mass gathering, as well as social distancing also led to pressure on forests because they were more easily accessible for food and cooking fuel during the lockdown (Gondwe, 2020; Maliszewska et al., 2020). Hence, COVID-19 can exacerbate deforestation in Malawi if proper control measures are not put in place in the forest sector. Therefore, this study expounds on literature to highlight the implication of COVID-19 on the forest sector in Malawi.

2 | This work is licensed under a Creative Commons Attribution 4.0 International License. 
In the Southern African Development Community (SADC) region, Malawi has the highest deforestation, which is represented by a net loss of some 30,000 to 40,000 hectares per year (Mauambeta et al., 2010). This forest loss is mainly attributed to agriculture expansion, infrastructure development, population growth, tobacco growing, brick making and excessive use of biomass (wood, charcoal, and agricultural waste) for cooking (Ngwira \& Watanabe, 2019; Gowela \& Masamba, 2002; Katumbiet al., 2015). Though the country's forest is declining, the COVID-19 has further led to a decline in forest area as people resolve to forests as an alternative means of livelihood. According to Senganimalunje et al. (2020), forests are important natural capital for forest-adjacent communities and play an important role in dealing with risks and shocks. Hence, the knowledge of the impact of COVID-19 on forests is important for building a sustainable economy, particularly around forest communities.

Similarly, there is a high rate of unemployment in Malawi and this was expected to be exacerbated by the pandemic, with an estimated loss in jobs at about
$3 \%$ as a result of the pandemic (International Labour Organization, ILO, 2020). Consequently, high unemployment will invariably lead to a fall back in the direct extraction of forest resources from the immediate environment for daily household use and to sell for profit (Coutts et al., 2019). This is because forests provide food, fuelwood, medicine, timber, employment and other non-timber products (NTFPs) that can sustain wellbeing. Thus, forest products are used to support household consumption as a safety net in times of shock and crisis as well as a way out of poverty (Angelsen \& Wunder, 2003; Djoudi et al., 2015, Porro et al., 2015). Hence, the role of forests can never be overemphasized, especially in Malawi where there is high dependence on forests by the rural and urban population because the majority of the population uses charcoal and firewood for cooking. Besides, forests provide over 75 percent of the total biomass supply and biomass energy contributes more than 90 percent of total primary energy consumption (Jumbe and Angelsen, 2011). Thus, as a result of the high dependence on forests in Malawi, it is eminent to review the likely implication of COVID-19 on the forest sector.

3 | This work is licensed under a Creative Commons Attribution 4.0 International License. 


\section{Conceptual Framework}

Figure 1: Implication of COVID-19 on demand \& supply of forest products and management

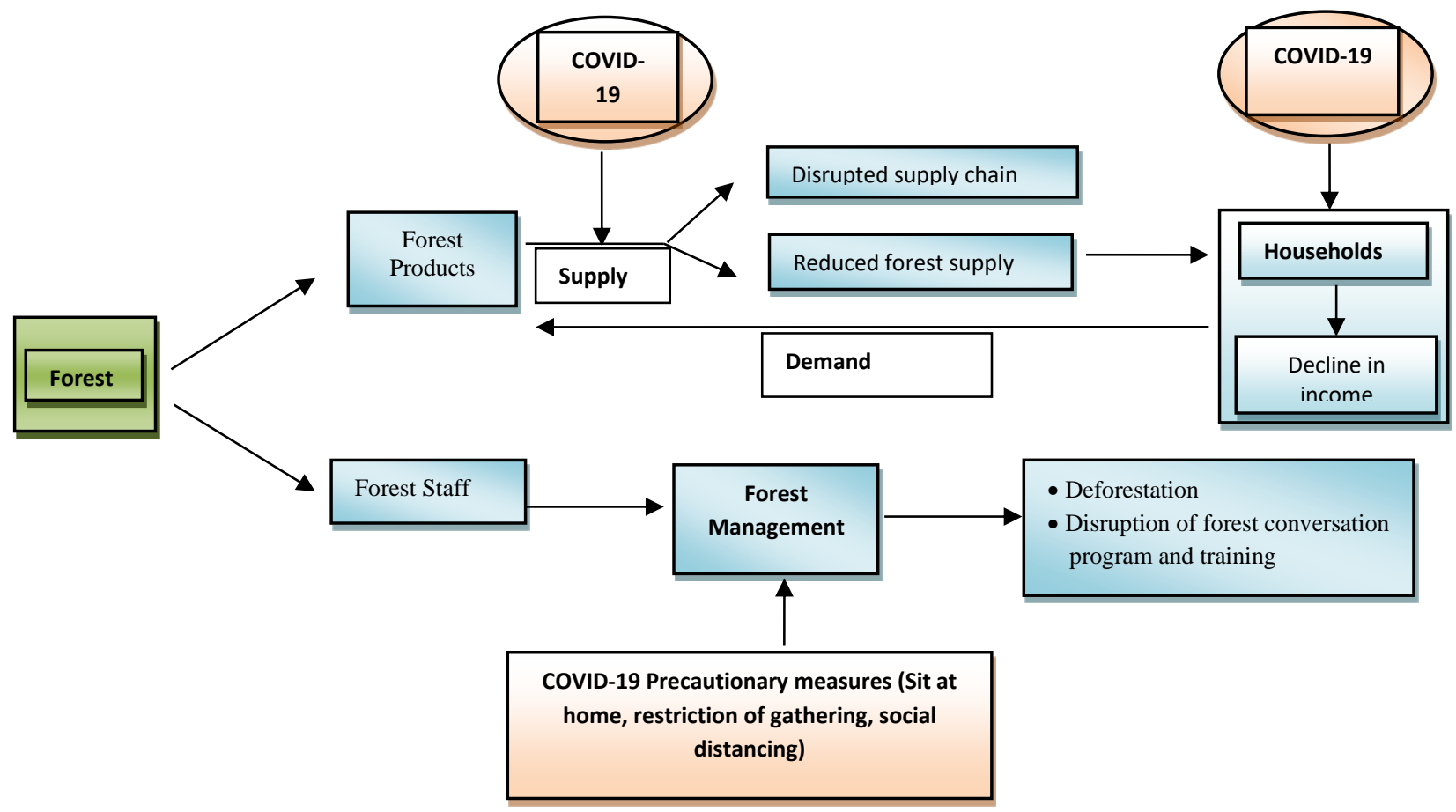

\section{METHODOLOGY}

Literature was reviewed to expound on the impact of COVID-19 on the forest sector in Malawi. Keyword searches in electronic databases such as Google Scholar, Google search, World Bank website, International Labour Organization website and Journal articles were conducted as part of the review. Review search terms included 'COVID-19', 'Impact of COVID-19', 'Forest sector in Malawi', 'Malawi's economy', and 'Impact of COVID-19 on Malawi's economy'. The review was divided into two phases. In the first, abstracts and articles were retrieved and assessed based on their relevance to the research as well as credibility and accuracy of their reports. Full papers were retrieved and assessed for final review for abstracts and articles that met the review criteria in phase 1 .

\section{DISCUSSIONS}

\section{Forest in Malawi}

Malawi's Forests cover around 20.4 percent of the land area and supply a variety of timber and nontimber products such as mushrooms, thatch grass, wild fruits, wild animals, medicinal plants, honey) (FAO, 2015). The forest resources of Malawi are classified into natural woodland, forestry plantations, and woodlots. The natural woodland comprises forest reserves $\left(8,076 \mathrm{~km}^{2}\right)$, national parks and game reserves $\left(9,680 \mathrm{~km}^{2}\right)$, and customary forests $\left(8,843 \mathrm{~km}^{2}\right)$, totalling $26,428 \mathrm{~km}^{2}$ of forest land (Yaron et al., 2011). The forestry sector in Malawi is coordinated by the Ministry of Natural Resources, Energy and Mining. Currently. Malawi's forestry policy recognizes and empowers all resource users, particularly rural people, to play a greater role in forest resource management and control. Tree planting by various stakeholders, development of forest-based enterprises, involvement of local natural resource committees in the establishment and conservation of village forest

4 | This work is licensed under a Creative Commons Attribution 4.0 International License. 
areas, involvement of the private sector in the exploitation and management of forests, and the formation of local village-level institutions such as Village Natural Resource Committees are all examples of best practices in the forest sector.

Forests make up $12 \%$ of Malawi's natural capital, they serve a critical role in supporting agriculture which is the country's mainstay, by preventing soil erosion, maintaining soil fertility, and regulating water flow (Hecht \&Kasulo, 2013; GoM, 2016). However, forests in Malawi have experienced a high deforestation rate estimated at $2.8 \%$ representing an annual average loss of 250,000 ha of forest cover. The high deforestation rate in the country is driven by agricultural expansion, population growth and the demand for timber and wood for energy (charcoal and firewood). More than $97 \%$ of households in Malawi rely upon on illegally and unsustainably sourced biomass (charcoal and firewood) for domestic cooking and heating energy.

Though forests are vulnerable to the impact of COVID-19 as a result of increased pressure on forests as a coping strategy, yet forests can be a pathway to the recovery of the impact of COVID19. The resilient nature of forests makes it important in risk and shock management, especially for households who rely on forests for food and income (ILO, 2020). Forests can also contribute to recovery after the pandemic, providing subsistence goods for rural communities and supporting local markets, increasing their resilience to future crises. Developing local and regional markets for forest products can also help maintain supply chains while offering income-generating and savings opportunities.

\section{Impact of COVID-19 on forest sector in Malawi}

Malawi recorded its first COVID-19 case in April 2020 as of September 2020, Malawi had recorded 5,593 cases, 3516 recoveries, 1902 active cases and 175 deaths (Ministry of Health, 2020; Worldometer, 2020). To curb the spread of COVID-19 in Malawi, several measures such as restriction of movement, closure of Malawian border and social distancing were put in place. Though there was no total lockdown in the country, just like in other parts of the world, COVID-19 was expected to slow down economic growth. According to Baulch et al. (2020), the GDP of Malawi is projected to fall between 4 and 5.2 percent over the 2020 calendar year giving rise to about 1.1 million people, the majority in rural areas, temporarily falling into poverty. Also, the COVID-19 has disrupted the Malawi Development Growth strategy (MDGs III), which is supposed to run through 2017 to 2022, aiming at spurring growth in the country. The key priority areas of the MDG III affected by the COVID-19, one of such areas is agriculture (GoM, 2017). Despite agriculture being the contributor to Malawi's GDP, forests support agricultural production and contribute $6.2 \%$ to the country's GDP (Yaron et al., 2011). Forest also serves as a source of livelihood, particularly to rural households and is the major source of cooking energy (Jumbe, 2009; Chibwana et al., 2013). Hence the knowledge of the impact of COVID-19 on Malawi's forest is core in building a resilient and sustainable economy. This paper discusses three ways the implication of COVID-19 will be felt on the forest sector, and they include; demand, supply and management of forests.

\section{COVID-19 and the Demand and Supply in Malawi's Forest Sector}

The major demands on forest resources are forest services, timber, non-timber forest products and wood energy. Furthermore, the COVID-19 pandemic coupled with population growth, high dependence on charcoal as the main source of energy for domestic use, growing pressure for cropland and frequent introduction of forest invasive pest species are placing increased demands on forest(FAO, 2015).Consequently, the majority of households experience declines in income and loss of jobs as a result of COVID-19 leading to increased demand for forest products as households resolve to forests as an alternative means of livelihood (Thula et al., 2020). Similarly, poverty which is already prevalent in Malawi has been exacerbated by the COVID-19 pandemic causing a rise in demand and exploitation of forest resources. This is so because, during a crisis, forests act as safety nets, especially among rural poor people who turn to forest resources for their subsistence needs (Attah, 2021). Besides, according to Nerfa et al. (2019), there is an interrelation between poverty and dependence on forests, as poor households rely on forests for food 
and cooking fuel. Hence, forests serve as safety nets for the rural poor in times of unanticipated scarcity or as gap fillers in times of regular seasonal shortfalls (Angelsen \& Wunder, 2003; Shackleton \& Shackleton, 2004; Paumgarten, 2005). Therefore, the impact of COVID-19 will lead to increased demand for forest products for food, medicine and wood fuel, which further lead to deforestation and forest degradation if control measures are not put in place. On the other hand, COVID-19 may lead to demand shortage, as a negative supply shock of timber due to the restriction of movement and closure of border can lead to a demand shortage (Guerrieri et al., 2020).

On the supply side, the impact of COVID-19 will also be felt because forest supply diverse forest products and the supply chain of these forest products are being disrupted by the pandemic. Generally, production and supply, international trade, global value chains (GVCs) are being subject to the direct hit of the pandemic crisis (Guerrieri et al., 2020). This is reflected in the forest sector as the restrictions on movement affects the entire value chains, particularly the transport of forest products, thereby affecting forest-related livelihoods and businesses. According to the Malawi Confederation of Chambers of Commerce and Industry (MCCCI, 2020), there is expected to be a disturbance of trade links within and with the rest of the world as a result of COVID-19.

\section{Forest Management -Extension, Plantation Law Enforcement}

In Malawi, the COVID-19 pandemic affected forest management in diverse ways, such as extension, plantation and law enforcement. The extension workers who train and build the capacity of forest communities with regards to building sustainable forests were affected by the COVID-19 precautionary measures. These workers were asked to work from home to curb the spread of COVID19, and the restrictions in public and private gatherings also affected the provision of technical assistance for communities on forest management by extension workers (Attah, 2021). Also, plantation of forests was affected as the establishment of tree nurseries supervision and actual planting process was disrupted by "work from home" policy. Forest guards and patrolmen who look after the forest were advised to work from home, making the forest vulnerable to deforestation and degradation. According to the African Union (2020), the pandemic is anticipated to result in increased deforestation rates since national forest institutions are likely to struggle to retain staff as funding for forest protection activities declines. Similarly, as countries prioritize response to the pandemic, there is a tendency of less focus on legal enforcement and sustainable forest management. This poses a threat to Malawi's forest, which is already facing poor governance such as weak institutional and technical capacity, lack of coordination.

\section{CONCLUSION}

The COVID-19 pandemic has affected various sectors of Malawi's economy with the forest sector not left out. Though the impact of the pandemic on the forest sector is yet to be fully quantified, this article gives an insight into the implication of the pandemic on the forest sector. The demand and supply of forest products as well as forest management has been affected by the COVID-19 pandemic. This is because of COVID-19 precautionary measures such as the closure of border and restriction of movements as well as restrictions in a large gathering. Forests served as a safety net for households who experience a decline in income, thereby leading to increased demand for forest products. Similarly, the pandemic disrupted forest supply chains as well as forest management processes. Hence, it is important that the possible impact of COVID-19 on forests be incorporated into the economy's pathway of COVID-19 recovery policy as forests can help in building a resilient economy.

\section{REFERENCES}

African Union. (2020). African forests and the COVID-19 pandemic. Addis Ababa: African Union.

Angelsen, A., \&Wunder, S. (2003). Exploring the forest-poverty link. CIFOR occasional paper, 40, 1-20.

Attah, A. N. (2021). Initial Assessment of the Impact of COVID-19 on Sustainable Forest 
Management African States.United Nations Forum on Forests Secretariat

Baulch, B., Botha, R., \&Pauw, K. (2020). The short-term impacts of COVID-19 on the Malawian economy 2020-2021: A SAM multiplier modeling analysis (Vol. 37). Intl Food Policy Res Inst.

Chibwana, C., Jumbe, C. B., \& Shively, G. (2013). Agricultural subsidies and forest clearing in Malawi. Environmental Conservation, 40(1), 60-70.

Congressional Research Service (CRS). (2021). Global Economic Effects of COVID-19. Congressional Research Service R46270. https://fas.org/sgp/crs/row/R46270.pdf

Coutts, C., Holmes, T., \& Jackson, A. (2019). Forestry policy, conservation activities, and ecosystem services in the remote Misuku Hills of Malawi. Forests, 10(12), 1056.doi:10.3390/f 10121056

Djoudi, H., Vergles, E., Blackie, R. R., Koame, C. K., \& Gautier, D. (2015). Dry forests, livelihoods and poverty alleviation: understanding current trends. International Forestry Review, 17(2), 54-69.

Food and Agriculture Organisation (FAO). (2015). Southern Africa's Forests and People. XIV World Forestry Congress

Gondwe, G. (2020). Assessing the Impact of COVID-19 on Africa's Economic Development. UNCTAD/ALDC/MISC/2020/3. United Nations Conference on Trade and development. https://unctad.org/en/PublicationsLibrary/aldem isc2020d3_en.pdf

Gowela, J. P., \& Masamba, C. R. (2002). State of forest and tree genetic resources in Malawi. Food and Agriculture Organization of the United Nations: Rome, Italy.

GoM. (2020). The Third National Communication of the Republic of Malawi to the Conference of the Parties (COP) of the United Nations Framework Convention on Climate Change Malawi's updated nationally determined contribution 105 (UNFCCC). September,
2020.19 (note that the final published version was submitted February, 2021).

Guerrieri, V., Lorenzoni, G., Straub, L., \& Werning, I. (2020). Macroeconomic implications of COVID-19: Can negative supply shocks cause demand shortages? (NBER Working Paper No. 26918). National Bureau of Economic Research. http://www.nber.org/papers/w26918

Haleem, A., Javaid, M., \& Vaishya, R. (2020). Effects of COVID-19 pandemic in daily life. Current medical research and practice, 10(2), 78 .

Hecht, J., \& Kasulo, V. (2013). Development of Forest Valuation Systems Malawi-Technical Report. Cardno Emerging Markets.

International Labour Organisation (ILO). (2020). ILO Sectoral Brief: Impact of COVID-19 on the forest sector. International Labour Organisation

Jumbe, C. B. L. \& Angelsen, A. 2011. Modelling choice of fuelwood source among rural households in Malawi: A multinomial Probit analysis. Energy Economics. 33(5): 732- 738

Katumbi, N., Nyengere, J., \& Mkandawire, E. (2015). Drivers of deforestation and forest degradation in Dzalanyama forest reserve in Malawi. Int. J. Sci. Res, 6, 889-893.

Malawi Government (GOM). (2016). National Forest Policy. Malawi Government.

Malawi Government, GoM. (2017). The Malawi growth and development strategy (MDGs) III building a Productive, Competitive and Resilient Nation

Maliszewska, M., Mattoo, A., \& Van Der Mensbrugghe, D. (2020). The potential impact of COVID-19 on GDP and trade: A preliminary assessment. World Bank Policy Research Working Paper, (9211). http://documents1.worl dbank.org/curated/en/295991586526445673/pd f/The-Potential-Impact-of-COVID-19-on-GDPa

Mauambeta, D. Chitedze, D. \& Mumba, R. (2010). Status of Forests and Tree Management in

7 | This work is licensed under a Creative Commons Attribution 4.0 International License. 
Malawi. Lilongwe, Malawi. Coordination Union for Rehabilitation of the Environment (CURE):

MCCCI. (2020). Impact of Coronavirus (Covid 19) on businesses in Malawi. Malawi Confederation of Chambers of Commerce and Industry. https://www.mccci.org/index.php?option=com_ content\&view=article \&id=285:impact-ofcorona-virus-covid19-on-businesses-inmalawi\&catid=19: news\&Itemid=138

Ministry of Health (MoH). (2020). Covid-19 National Information Dashboard. Ministry of Health Malawi. https://covid19.health.gov.mw/

Nerfa, L., Rhemtulla, J. M., \& Zerriffi, H. (2020). Forest dependence is more than forest income: Development of a new index of forest product collection and livelihood resources. World Development, 125, 104689.

Ngwira, S., \& Watanabe, T. (2019). An analysis of the causes of deforestation in Malawi: a case of Mwazisi. Land, 8(3), 48.

Ozili, P. K., \& Arun, T. (2020). Spillover of COVID-19: Impact on the Global Economy. Munich Personal RePEc Archive. https://mpra.ub.uni-muenchen.de/99850/

Paumgarten, F. (2005). The role of non-timber forest products as safety-nets: a review of evidence with a focus on South Africa. GeoJournal, 64(3), 189-197.

Porro, R., Lopez-Feldman, A., \& Vela-Alvarado, J. W. (2015). Forest use and agriculture in Ucayali, Peru: Livelihood strategies, poverty and wealth in an Amazon frontier. Forest Policy and Economics, 51, 47-56.

Senganimalunje, T.C., Chirwa, P.W., \& Babalola, F.D. (2020). Exploring the Role of Forests as Natural Assets in Rural Livelihoods and Coping Strategies Against Risks and Shocks in Dedza east, Malawi. Journal of Sustainable Forestry, $1-23$.

Shackleton, C., \& Shackleton, S. (2004). The importance of non-timber forest products in rural livelihood security and as safety nets: a review of evidence from South Africa. South African Journal of Science, 100(11), 658-664.
Thula, M., Matola, J. U., Nyasulu, T., \& Nyasulu, K. (2020). Assessment of the Impact of COVID19 on Employment in Malawi. Employer's Consultative Association of Malawi (ECAM) and the International Labour Organization (ILO).

United Nations, UN, (2021). Building forward together: Ending poverty, respecting all people and our planet. https://www.un.org/en/observan ces/day-for-eradicating-poverty

World Bank. (2021). Malawi Overview: Development news, research, data. https://www.worldbank.org/en/country/malawi/ overview\#1

World Bank. (2020). Malawi Economic Monitor: In times of COVID-19, protecting the lives, livelihoods and future of Malawians. World Bank. https://www.worldbank.org/en/country/m alawi/publication/malawi-economic-monitor-intimes-covid-19-protecting-lives

Worldmeter. (2020). Malawi Coronavirus cases. Worldmeter. https://www.worldometers.info/co ronavirus/country/malawi/

Yaron, G., Mangani, R., Mlava, J., Kambewa, P., Makungwa, S., Mtethiwa, A., Munthali, S., Mgoola W. \& Kazembe, J. (2011). Economic valuation of sustainable natural resource use in Malawi. Ministry of Finance and Development Planning, Government of Malawi. https://www.undp.org/content/dam/malawi/docs /environment/Economic\%20Valuation\%20of\% 20Sustainable\%20Natural\%20Resources\%20Us e\%20in\%20Malawi.pdf

8 | This work is licensed under a Creative Commons Attribution 4.0 International License. 